\title{
KEARIFAN LOKAL DALAM TRADISI MANCOLIAK ANAK PADA MASYARAKAT ADAT SILUNGKANG
}

\author{
LOCAL WISDOM IN THE "TRADITION OF MANCOLIAK ANAK" \\ AT THE SILUNGKANG INDIGENOUS PEOPLES \\ Arni Chairul \\ Politeknik Kesehatan Kementrian Kesehatan Medan Jurusan Keperawatan \\ Jalan Bunga Ncole Medan Tuntungan-Sumatra Utara \\ e-mail: arnichairul76@gmail.com
}

DOI: $10.36424 / j p s b . v 5 i 2.86$

\author{
Naskah Diterima:18 Juli 2019 Naskah Direvisi: 9 Oktober 2019 \\ Naskah Disetujui: 9 Oktober 2019
}

\begin{abstract}
Abstrak
Kearifan lokal merupakan prinsip-prinsip dan cara-cara tertentu yang dianut, dipahami, dan diaplikasikan oleh masyarakat lokal dalam berinteraksi dan berinterelasi dengan lingkungannya dan sebagai hasil produksi tradisi yang hidup, dan tumbuh secara turun-temurun bersama masyarakat adat. Ia berfungsi sebagai pembentuk \& penuntun perilaku manusia dalam kehidupan yang bersifat bijaksana, penuh kearifan, dan bernilai baik yang tertanam dan diikuti oleh anggota masyarakatnya. Bahkan dalam masyarakat ia dianggap sebagai entitas penentu harkat dan martabat manusia yang memiliki kecerdasan, pengetahuan dan moral yang menjadi dasar pembangunan peradaban suatu masyarakat. Ketidakberdayaan masyarakat adat dalam mempertahankan eksistensinya merupakan ancaman yang serius untuk kelanjutan tradisi berikutnya, seperti halnya tradisi mancoliak anak pada masyarakat adat Silungkang yang sudah mulai hilang dan wajib dilestarikan keberadaanya. Penelitian ini bertujuan untuk mengetahui nilai-nilai kearifan lokal dalam tradisi mancoliak anak pada masyarakat adat Silungkang. Penelitian ini menggunakan pendekatan kualitatif dengan metode etnografi sedangkan data diperoleh melalui wawancara, dan dokumentasi. Penelitian ini menemukan kearifan lokal tersebut adalah : agama mengajarkan adat memakai, saling tenggang rasa, berat sama dipikul ringan sama dijinjing, saling menjaga hubungan kekeluargaan, hidup dikandung adat mati dikandung tanah,dapat musibah diimbaukan dapat kebaikan diimbaukan, yang tua dihormati yang muda disayangi yang sebaya dikawani, dan seia sekata.
\end{abstract}

Kata kunci: kearifan lokal, tradisi, masyarakat adat 


\begin{abstract}
Local wisdom is certain principles and methods adopted, understood, and applied by local communities in interacting and interrelating with their environment and as a result of the production of traditions that live and grow for generations with indigenous peoples.Local wisdom functions as formers and guide of human behaviour in the life that the wise, and good value which exists and be followed by the community. Even in the community, it is considered adetermining entity of the human dignity which has intelligence, knowledge and moral which is the basic forthe moral development of the community. The powerlessness of indigenous peoples in maintaining their existence is a serious threat for continuation of the next tradition, like a the tradition of Mancoliak Anak at the Silungkang indigenous people which has begun to disappear and must be maintained.This research aims to find out local wisdom in the tradition of Mancoliak anak at the Silungkang indigenous people.This research uses a qualitative approach with ethnographic methods while data is obtained through interviews, and documentation. This research findthat local wisdom are : religion teaches custom use it, tolerance with each other, happy and difficult to face together, maintain family relations with each other, life was conceived by adat died was conceived by the land, both bad news and good news are told, the old are respected the young are loved the same age are accompanied, and cooperate with each other
\end{abstract}

Keywords: local wisdom, traditions, indigenous people

\title{
PENDAHULUAN
}

Setiap keanekaragaman kebudayaan suku bangsa di Indonesia memiliki keunggulan lokal atau memiliki kearifan lokal (local wisdom) yang berbeda-beda. Kearifan lokal ini tercermin dalam kebiasaan hidup masyarakat setempat yang telah berlangsung lama. Contohnya dapat ditemui dalam bentuk nyanyian, pepatah, petuah, ajaran, dan semboyan yang melekat dalam acara pernikahan, kematian, melahirkan dan sebagainya. Dalam penelitian yang telah dilakukan oleh Widyaningrum (2017) dengan judul Tradisi Adat Jawa dalam Menyambut Kelahiran Bayi (Studi Tentang Pelaksanaan Tradisi Jagongan Pada Sepasaran Bayi) di Desa Harapan Harapan Jaya Kecamatan Pangkalan Kuras Kabupaten Pelalawan,ia menemukan bahwa tradisi jagongan bayi sangat cocok dan menjadi ciri khas sendiri dari masyarakat Jawa pedesaan yang mengutamakan rasa kekeluargaan dan rasa empati. Tradisi jagongan bayi hanya dilakukan ketika adanya kelahiran bayi saja dan dilaksanakan sejak kelahiran bayi sampai dengan 
tujuh harinya. Tradisi jagongan bayi diisi dengan permainan kartu remi, domino, catur, dan permainan lainnya. Manfaat dari adanya pelaksanaan jagongan bayi, yaitu : ibu yang baru saja melahirkan merasa terhibur karena suasana rumah menjadi ramai, bisa berkumpul dengan sanak saudara, persediaan peralatan dan perlengkapan bayi terbantu sehingga hubungan antar warga desa semakin erat.

Demikian juga halnya di Silungkang, daerah ini memiliki tradisi dalam menyambut kelahiran seorang anak yang disebut dengan tradisi Mancoliak anak. Silungkang merupakan salah satu desa atau nagari yang terletak di Kota Sawahlunto, Provinsi Sumatra Barat yangmemiliki luas wilayah $247,8 \mathrm{~km}^{2}$. Dilihat dari sudut demografi, Silungkang dihuni oleh 8.644 jiwa penduduk (Data Monografi Per Desember 2004 Kenagarian Silungkang), sedangkan dari segi geografis, Nagari Silungkang ini terletak digugusan Bukit Barisan dalam sebuah cekungan yang tidak begitu luas dengan ketinggian rata-rata 239-450 meter di atas permukaan laut dan dikelilingi oleh bukit-bukit batu yang cukup terjal dan tandus sehingga Silungkang diberi julukan yakni "Nagari Kuali”. Nagari Silungkang ini dibelah dua oleh Sungai Batang Lasi yang bermuara pada Sungai Ombilin, dan dilalui oleh dua sarana transportasi yaitu jalan raya dan jalan kereta api. Hal ini menyebabkan daerah Silungkang tidak memiliki banyak tradisi budaya seperti daerah lain di Provinsi Sumatra Barat, hanya kain tenun songket Silungkang yang dikenal luas, sementara tradisi mancoliak anak belum banyak diketahui masyarakat luas, bahkan oleh masyarakat Silungkang itu sendiri. Kenyataan ini sangatlah ironis, karena dalam tradisi ini banyak hal yang mengandung nilai-nilai kearifan lokal yang bisa dijadikan prinsip hidup bagi generasi berikutnya dan jika dibiarkan lambat laun akan sirna diterjang arus globalisasi.Oleh karena itulah artikel ini ditulis untuk membahas tentang nilai kearifan lokal yang terdapat dalam tradisi mancoliak anak pada masyarakat adat Silungkang yang dianggap perlu dilestarikan dan dipertahankan keberadaannya.

Menurut Zulkarnain, dkk (2008:72), kearifan lokal merupakan prinsipprinsip dan cara-cara tertentu yang dianut, dipahami, dan diaplikasikan oleh masyarakat lokal dalam berinteraksi dan berinterelasi dengan lingkungannya dan ditransformasikan dalam bentuk sistem nilai dan norma adat. Bahkan, kearifan 
lokal dianggap sebagai hasil produksi kebiasaan yang hidup dan tumbuh bersama masyarakat adat desa / adat daerah dan diimplementasikan dalam kehidupan sosial dan kekerabatan dalam masyarakat (Salim, 2016:245).Teori ini diperjelas pula oleh Aprianto (2008:12) yang menyebutkan bahwa kearifan lokal dapat berupa adat kebiasaan atau etika yang menuntun perilaku manusia dalam kehidupan sangat terkait dengan kondisi wilayah dan komunitas yang diwariskan secara turun temurun. Jadi, dapat disimpulkan bahwa keberlangsungan kearifan lokal akan tercermin dari kebiasaan yang mengandung nilai-nilai sebagai penuntun perilaku manusia yang berlaku dalam kelompok masyarakat tertentu.

Terkait dengan nilai-nilai yang berlaku di masyarakat maka semua kearifan lokal ini harus dihayati, dipraktikkan, diajarkan, dan diwariskan dari generasi ke generasi, sekaligus dapat membentuk pola perilaku manusia terhadap sesama manusia, alam maupun gaib, Keraf (dalam Romarak Ap, 2018 :196-197). Dengan kata lain, kearifan lokal terbentuk sebagai keunggulan budaya lokal masyarakat setempat maupun kondisi geografis dalam arti luas, meskipun bernilai lokal tetapi nilai yang terkandung di dalamnya dianggap sangat universal, Satriani (dalam Bakhtiar,2016:658). Ditambahkan pula oleh Prasetyo (2013: 3) yang mengatakan bahwa kearifan lokal sebagai gagasan setempat yang bersifat bijaksana, penuh kearifan, bernilai baik yang tertanam dan diikuti oleh anggota masyarakatnya. Bahkan dalam masyarakat ia dianggap sebagai entitas penentu harkat dan martabat manusia (Geertz, 2007). Hal ini menunjukkan bahwa dalam kearifan lokal terdapat kecerdasan pengetahuan dan moral yang menjadi dasar pembangunan peradaban suatu masyarakat.

Dari uraian tersebut dapat dilihat besarnya fungsi dari kearifan lokal dalam masyarakat. Adapun fungsi tersebut menurut Haba, (dalam Abdullah, 2010:7-8), yaitu : 1) penanda identitas sebuah komunikasi; 2) elemen perekat / aspek kohesif lintas warga, lintas agama, dan kepercayaan; 3) unsur kultural yang ada dan hidup dalam masyarakat (bottom up); 4) warna kebersamaan sebuah dan kelompok dengan meletakkannya di atas common ground/kebudayaan yang dimiliki; 6) mendorong terbangunnya kebersamaan, apresiasi sekaligus sebagai sebuah mekanisme bersama untuk menepis berbagai kemungkinan yang meredusir 
bahkan merusak solidaritas komunal yang dipercaya dan disadari tumbuh di atas kesadaran bersama dari sebuah komunitas terintegrasi.

Kearifan lokal yang tercermin dalam kebiasaan hidup masyarakat yang telah berlangsung lama dalam perkembangannya dapat berubah wujud menjadi tradisi, meskipun prosesnya membutuhkan waktu yang sangat panjang. Suatu kebiasaan yang turun temurun dalam sebuah masyarakat dengan sifatnya yang luas disebut dengan tradisi, yang meliputi segala kompleks kehidupan, sehingga tidak mudah disisihkan dengan perincian yang tepat dan pasti, terutama sulit diperlakukan serupa atau mirip, karena tradisi bukan objek yang mati, melainkan alat yang hidup untuk melayani manusia yang hidup pula, Pintenate dan Bukhari (2017:911). Selaras dengan pengertian tersebut menurut Kamus Besar Bahasa Indonesia (2002) menyebutkan bahwa tradisi diartikan sebagai kebiasaan turuntemurun (dari nenek moyang) yang masih dijalankan dalam masyarakat; atau juga penilaian atau anggapan bahwa cara-cara yang telah ada merupakan yang paling baik dan benar. Senada pula menurut Koentjaraningrat (1993), kata tradisi berasal dari Bahasa Latin traditium yang berarti diteruskan, kemudian berkembang pengertiannya menjadi sebagai sesuatu yang telah diinginkan untuk sejak lama dan menjadi bagian dari kehidupan suatu kelompok masyarakat. Berdasarkan pengertian dari beberapa konsep di atas dapat disimpulkan bahwa tradisi adalah suatu kebiasaan turun-temurun yang telah dilakukan sejak lama dan telah menjadi bagian dari kehidupan suatu kelompok masyarakat.

Adapun demikian, nilai-nilai kearifan lokal yang diwariskan para leluhur bangsa Indonesia yang sampai saat ini sebetulnya masih ada dan terjaga, dimana nilai-nilai kearifan lokal tersebut dapat dijumpai pada masyarakat adat (Sukmayadi,2018:21). Menurut Konradus, (2018:83), masyarakat adat (indigenous peoples) adalah suku bangsa yang berdiam di negara merdeka yang kondisi sosial, budaya dan ekonominya berbeda dengan kelompok masyarakat lain atau suku bangsa yang telah memahami suatu negara sejak masa kolonialisasi yang memiliki kelembagaan ekonomi, budaya dan politik sendiri. Lagi pula, ia lahir dari dan berkembang bersama, dan dijaga oleh masyarakat itu sendiri, Ade Saptomo (dalam Sabandiah dan Endra Wijaya 2018: 336). Dalam konteks ini, 
ketidakberdayaan masyarakat adat dalam mempertahankan keberadaannya merupakan ancaman yang serius untuk kelanjutan nilai tradisi berikutnya, karena hal yang paling mendasar dari tradisi yakni adanya informasi yang diteruskan dari generasi ke generasi baik dalam bentuk tertulis maupun tak tertulis. Tanpa adanya hal itu, suatu tradisi akan punah, Pudentia (dalam Anton dan Marwati, 2015:3) sehingga kepunahan suatu tradisi dapat mengakibatkan juga punahnya kearifan lokal yang dimiliki oleh suku bangsa itu. Hal ini jelas berdampak pula dengan hilangnya jati diri dari suatu generasi penerus bangsa yang sejatinya selalu melekat dan menjadi pedoman hidup mereka.

\section{METODE PENELITIAN}

Penelitian ini menggunakan pendekatan kualitatif dengan metode etnografi. Menurut Creswell (2012:462), metode etnografi adalah prosedur penelitian kualitatif untuk menggambarkan, menganalisis, dan menafsirkan unsurunsur dari sebuah kelompok budaya seperti pola perilaku, kepercayaan, dan bahasa yang berkembang dari waktu ke waktu. Adapun teknik pengumpulan data dalam penelitian ini menggunakan : 1) teknik wawancara, di mana wawancara dilakukan dengan salah satu datuk pemangku adat di Karapatan Adat Nagari (KAN) Kanagarian Silungkang sehingga diperoleh gambaran serta penjelasan tentang nilai-nilai kearifan lokal dalam tradisi mancoliak anak; dan 2) dokumentasi. Adapun dokumentasi yang digunakan adalah berupa naskah hasil pengamatan dari Datuk Rangkayo dengan judul Adat Istiadat dan Monografi Nagari Silungkang, yang diterbitkan oleh Karapatan Adat Nagari (KAN) Kanagarian Silungkang tahun 2004. Sedangkan analisis datanya menggunakan teknik analisis induktif dari Miles dan Huberman yakni menganalisis data yang ada melalui : 1) reduksi data. Data dirangkum, dipilih hal-hal pokok yang penting, diberi susunan yang lebih sistematis, sehingga lebih mudah dikendalikan sesuai dengan tujuan penelitian yakni tentang nilai-nilai kearifan lokal dalam tradisi mancoliak anak, 2) penyajian data dalam bentuk tabel. Data observasi berupa catatan-catatan tentang tradisi mancoliak anak pada masyarakat adat Silungkang dibuat pentabelan agar peneliti mudah membaca data; dan 3) penarikan 
kesimpulan/verifikasi. Verifikasi berarti memeriksa kebenaran data penelitian, baik melalui naskah yang dapat dilihat maupun percakapan langsung dalam wawancara yang dapat didengar tentang nilai-nilai kearifan lokal dalam tradisi mancoliak anak, kemudian dilakukan penarikan kesimpulan dari semua data yang diperoleh.

\section{PEMBAHASAN}

\section{Nilai -Nilai Kearifan Lokal dalam Tradisi Mancoliak Anak}

Berdasarkan temuan yang diperoleh maka terdapat 7 prosesi yang dilakukan dalam tradisi mancoliak anak, adapun pembahasannya adalah sebagai berikut :

1) Mengazankan atau mengiqomatkan (Ketika si anak baru lahir). Kearifan lokal atau prinsip yang dianut masyarakat adat dalam prosesi ini disebut dengan "Syarak mangato adat memakai" (agama mengajarkan; adat memakai), mengandung nilai (Zulkarnain, dkk) bahwa orang tua si anak telah melakukan kewajibannya untuk mengazankan atau mengiqomatkan anaknya sesuai dengan ajaran agama Islam yang dianutnya.Nilai kearifan lokal dalam prosesi ini dapat dikategorikan berfungsi sebagai penanda identitas komunikasi (Haba), yakni identitas seorang muslim, terlihat dari tindakan mengazankan atau mengiqomatkan anak yang baru lahir yang dilakukan oleh ayah kandung si anak atau kalau berhalangan bisa diwakilkan oleh seorang pandito. Nilai ini sekaligus membentuk pola perilaku manusia (Keraf) yang bijaksana dan bernilai baik (Prasetyo), yakni perilaku taat dari orang tua si anak untuk mengikuti ajaran agama yang dianutnya.

2) Mancoliak (Usia anak 3-7 hari). Kearifan lokal yang tersirat dalam prosesi ini adalah : a)"Urang kampuang dipatenggangkan"(menenggang orang kampung), yang mengandung nilai bahwa pihak keluarga si anak menghargai keberadaan orang kampung. Nilai kearifan lokal ini menurut Haba dapat berfungsi sebagai :1) elemen perekat lintas warga, agama dan kepercayaan ; 2) unsur budaya yang ada dan hidup alam masyarakat ; 3) mekanisme kebersamaan dalam komunitas yang 
terintegrasi. Hal ini terlihat dari ditetapkannya hari Senin sebagai waktu berkunjung bagi orang kampung untuk melihat si anak karena pada hari itu orang kampung banyak memiliki waktu luang. Sedangkan dari sudut pandang Keraf nilai ini juga turut serta membentuk pola perilaku manusia yang bersifat bijaksana, arif dan baik (Prasetyo), yakni perilaku saling menghormati dan menghargai orang lain, ; b)"Barek sapikua ringan sajinjiang" (berat sama dipikul ringan sama dijinjing), yang mengandung nilai bahwa orang tua si anak menghargai atas perhatian dari pihak keluarga dan orang kampungnya. Menurut Haba nilai ini dapat berfungsi sebagai : 1) elemen perekat lintas warga, agama dan kepercayaan; 2) unsur budaya yang ada dan hidup dalam masyarakat ; 3) mekanisme kebersamaan dalam komunitas yang terintegrasi. Hal ini terlihat dengan berkunjungnya pihak keluarga untuk melihat si anak, di mana kunjungan pertama yang dilakukan itu berasal dari keluarga utama yakni induak bako si anak, kemudian dilanjutkan dengan kunjungan oleh orang yang sekampung dengan ibu si anak, dikunjungi oleh seluruh kerabat karib dan para tetangga. Hal ini mengakibatkan terbentuknya pola perilaku manusia (Keraf) yang bersifat bijaksana, arif dan baik (Prasetyo), yakni perilaku saling menghargai, tolong menolong dan membantu orang lain, ; c) "Baranak pisang barinduak bako" (beranak pisang berinduk bako), yang mengandung nilai bahwa pihak keluarga ayah si anak (induak bako) selalu memberi perhatian dan menjaga hubungan kekerabatan dengan orang tua si anak. Menurut Haba nilai ini dapat berfungsi sebagai : 1) penanda identitas komunikasi, yakni identitas/ciri khas dari suku Minangkabau ; 2) unsur budaya yang ada dan hidup dalam masyarakat. Hal ini terlihat dari tindakan semua saudara perempuan dari pihak ayah si anak turut serta berkewajiban dalam memberi makanan bagi keluarga kemenakannya yang baru lahir. Adapun ketika datang melihat si anak, barang yang dibawa oleh kerabat jauh berupa 4 buah sabun dan 2 liter beras sedangkan kerabat dekat (induak bakonya) membawa 10 buah sabun, 10 liter beras dan sehelai kain panjang. Hal ini juga berdampak terbentuknya pola perilaku manusia (Keraf) yang bersifat bijaksana, arif dan baik (Prasetyo) yakni perilaku saling menghargai, saling menyayangi dan saling tolong menolong, d) "Tenggang raso" (tenggang rasa), 
yang mengandung nilai bahwa si Pangka menghargai keberadaan pihak keluarganya (induak bakonya). Menurut Haba nilai ini dapat berfungsi sebagai : 1) penanda identitas komunikasi, yakni identitas/ciri khas dari suku Minangkabau; 2) unsur budaya yang selalu hidup dan ada di masyarakat ;3) mekanisme kebersamaan dalam komunitas yang terintegrasi. Hal ini terlihat dengan tindakan si Pangka yang hanya mengambil setengah bagian dari semua barang bawaan induak bakonyo kecuali kain panjang. Hal ini sekaligus mengakibatkan terbentuknya pola perilaku manusia (Keraf) yang bersifat bijaksana, arif dan baik (Prasetyo) yakni perilaku saling menghormati dan menghargai orang lain.

3) Mengakikahkan (Usia anak 7-14 hari). Prinsip yang dianut masyarakat adat Silungkang dalam prosesi ini disebut dengan "Syarak mangato adat memakai"(agama mengajarkan; adat memakai), mengandung nilai bahwa orang tua si anak telah melakukan kewajibannya untuk mengakikahkan anaknya sesuai dengan ajaran agama Islam yang dianutnya. Nilai kearifan lokal ini dapat berfungsi sebagai penanda identitas komunikasi (Haba), yakni identitas seorang muslim, dan terlihat dari tindakan orang tua si anak untuk mengakikahkan si anak dengan 2 ekor kambing bagi anak laki-laki atau dengan 1 ekor kambing bagi anak perempuan yang merupakan ungkapan rasa syukur si Pangka kepada Ilahi. Hal ini turut membentuk pola perilaku manusia (Keraf), yang bijaksana dan bernilai baik (Prasetyo), yakni perilaku taat dari orang tua si anak untuk mengikuti ajaran agama yang dianutnya.

4) Membawa turun mandi (Usia anak 15 hari - 1 bulan). Kearifan lokal yang tersirat pada prosesi ini adalah : a) "Iduik dikanduang adat, mati dikanduang tanah"(hidup dikandung adat, mati dikandung tanah), yang mengandung nilai bahwa orang tua si anak harus mengikuti pelaksanaan acara turun mandi si anak yang menjadi norma aturan masyarakat setempat. Menurut Haba nilai ini berfungsi sebagai 1) elemen perekat lintas warga, agama dan kepercayaan ; 2) unsur budaya yang selalu hidup dan ada di masyarakat ; 3) mekanisme kebersamaan dalam komunitas yang terintegrasi.Terlihat dengan adanya 
kepercayaan bahwa jika si anak dibawa mandi $k a$ luak/pancuran air sebelum diturunmandikan akan dikhawatirkan si anak akan mendapatkan suatu penyakit. Hal ini juga terlihat dari prosesi adat memandikan, dimulai dari si anak diasapi dengan asap pembakaran dari kertas dan daun dengan maksud agar si anak jadi orang alim, orang pintar dan tidak lupa pada rumah tangganya jika kelak sudah berumah tangga dan juga agar terhindar dari penyakit sawan (ayan); lalu dilewati dengan dengan api kecil, dengan maksud agar penglihatan si anak menjadi terang dan tidak buta; kemudian dilanjutkan dengan menguncang-guncangkan bambu berisi kemiri berkulit, dengan maksud agar pendengaran si anak menjadi lebih jelas dan nyaring ; kemudian dilumuri dengan bubuk kunyit dan kemiri, dengan maksud agar hati si anak bersih dan suci; dan terakhir dibasuh/dibilas dengan air bersih. Nilai ini sekaligus membentuk pola perilaku manusia (Keraf), yang bijaksana dan bernilai baik (Prasetyo), yakni perilaku taat orang tua si anak untuk mengikuti norma yang berlakudi masyarakat tersebut, ; b) "Dapek musibah bahambauan, mandapek kebaikan bahimbauan"(dapat musibah diimbaukan, dapat kebaikan diimbaukan), yang mengandung nilai bahwaorang tua si anak berkewajiban mengundang seluruh keluarga dan kerabat dekat untuk menghadiri acara turun mandi si anak. Menurut Haba nilai ini dapat berfungsi sebagai 1) elemen perekat lintas warga, agama dan kepercayaan ; 2) unsur budaya yang selalu hidup dan ada di masyarakat ; 3) mekanisme bersama dari sebuah komunitas yang terintegrasi. Hal ini ditunjukkan dengan beberapa orang pergi mangatoan (mengundang) orang yang akan dihadirkan pada acara turun mandi, terutamanya yang diundang itu adalah induak bako si anak beserta anggota kaumnya, dan seluruh sanak keluarga yang datang melihat anak sewaktu kelahirannya dahulu. Nilai ini sekaligus turut membentuk pola perilaku manusia (Keraf), yang bijaksana dan bernilai baik (Prasetyo), yakni perilaku saling menghargai, dan saling menghormati, c) "Baranak pisang barinduak bako"(beranak pisang berinduk bako),yang mengandung nilai bahwa pihak keluarga ayah si anak (induak bako) selalu memberi perhatian dan ikut serta dalam acara turun mandi si anak untuk menjaga hubungan kekerabatan dengan orang tua si anak. Menurut Haba nilai ini berfungsi sebagai :1) penanda identitas 
komunikasi, yakni identitas/ciri khas dari suku Minangkabau ; 2) unsur budaya yang ada dan hidup dalam masyarakat ; 3) mekanisme bersama dari sebuah komunitas yang terintegrasi, di mana semua saudara perempuan dari pihak ayah si anak turut serta berkewajiban dalam memberi makanan bagi keluarga kemenakannya yang baru lahir. Hal ini tampak dari kegiatan si induak bako si anak beserta seluruh sanak keluarga membawakan lauk pauk dan makanan khas Silungkang untuk acara turun mandi. Hal ini juga mengakibatkan terbentuknya pola perilaku manusia (Keraf) yang bersifat bijaksana, arif dan baik (Prasetyo) yakni perilaku saling menghargai, saling menyayangi dan saling tolong menolong. Sangat disayangkan karena sejak tahun 1985 acara turun mandi ini jarang sekali dilaksanakan, hanya oleh sebahagian warga yang ada di Sungai Cocang, Bukik Kociak, Bukik Kuniang dan Muarakalaban yang masih melaksanakannya.

5) Manyingau (Usia anak 1 bulan - 1 tahun). Kearifan lokal yang tersirat dalam prosesi ini adalah "Nan tuo dihormati, nan ketek disayangi, samo gadang baok bakawan" (yang tua dihormati, yang muda disayangi, yang sebaya dikawani), mengandung nilai bahwa pihak mintuo (istri mamak) selalu memberi perhatian dengan tujuan menjaga hubungan kekeluargaan dengan pihak si Pangka. Menurut Haba nilai ini berfungsi sebagai : 1) penanda identitas komunikasi, yakni identitas/ciri khas dari suku Minangkabau ; 2) unsur budaya yang ada dan hidup dalam masyarakat ; 3) mekanisme bersama dari sebuah komunitas yang terintegrasi. Hal ini tampak dari kunjungan dari pihak minto (istri mamak) ke pihak si Pangka. Hal ini juga membawa akibat terbentuknya pola perilaku manusia (Keraf) yang bersifat bijaksana, arif dan baik (Prasetyo) yakni perilaku saling menghargai, dan saling menyayangi tanpa membedakan usia.

6) Manjopuik (Usia anak $6-8$ bulan). Kearifan lokal yang tersirat pada prosesi ini adalah : a) "Saiyo sakato"(seia sekata), yang mengandung nilai bahwa semua pihak induak bako bekerjasama untuk melakukan prosesi penjemputan si anak. Menurut Haba nilai ini berfungsi sebagai : 1) penanda identitas komunikasi, yakni identitas/ciri khas dari suku Minangkabau ; 2) unsur kultural yang ada dan hidup 
dalam masyarakat ;3) mekanisme bersama dari sebuah komunitas yang terintegrasi. Hal ini terlihat dari tindakan semua induak bako si anak akan terlibat langsung dalam kegiatan mempersiapkan manjopuik si anak. Hal ini juga membawa dampak terbentuknya pola perilaku manusia (Keraf) yang bersifat bijaksana, arif dan baik (Prasetyo) yakni perilaku saling menghargai, saling tolong menolong dan saling percaya, ; b) “Baranak pisang barinduak bako”(beranak pisang berinduk bako), yang mengandung nilai bahwa pihak keluarga ayah si anak (induak bako) ikut serta dalam prosesi menjemput si anak untuk menjaga hubungan kekerabatan dengan orang tua si anak. Menurut Haba nilai ini berfungsi sebagai : 1) penanda identitas komunikasi, yakni identitas/ciri khas dari suku Minangkabau ; 2) unsur kultural yang ada dan hidup dalam masyarakat ;3) mekanisme bersama dari sebuah komunitas yang terintegrasi, di mana semua saudara perempuan dari pihak ayah si anak turut serta berkewajiban dalam memberi makanan bagi keluarga kemenakannya yang baru lahir. Hal ini terlihat dari kegiatan si induak bako membuat makanan khas Silungkang untuk si anak ketika akan menjemputnya. Hal ini juga membawa akibat terbentuknya pola perilaku manusia (Keraf) yang bersifat bijaksana, arif dan baik (Prasetyo) yakni perilaku saling menghargai, saling menyayangi dan saling tolong menolong.

7) Mengkhitankan (Usia anak perempuan 2-3 bulan, usia anak laki-laki 8-12 tahun). Kearifan lokal yang tersirat adalah "Syarak mangato adat memakai" (agama mengajarkan, adat memakai), yang mengandung nilai bahwa orang tua si anak telah melakukan kewajibannya untuk mengkhitankan anaknya sesuai dengan ajaran agama Islam yang dianutnya. Nilai kearifan lokaldi sini berfungsi sebagai penanda identitas komunikasi (Haba), yakni identitas seorang muslim, di mana terlihat dari tindakan mengkhitankan si anak, bagi anak laki-laki hukumnya wajib sementara bagi anak perempuan hukumnya sunah, sekaligus membentuk pola perilaku manusia (Keraf), yang bijaksana dan bernilai baik (Prasetyo), yakni perilaku taat dari orang tua si anak untuk mengikuti ajaran agama yang dianutnya. Berdasarkan uraian tersebut maka dapat dilihat keterkaitan antara kearifan lokal dengan tradisi, seperti pada Tabel 1, berikut ini : 
Tabel 1. Keterkaitan Kearifan Lokal dengan Tradisi

\begin{tabular}{|c|c|c|c|}
\hline No. & $\begin{array}{l}\text { Prosesi Tradisi } \\
\text { MancoliakAnak }\end{array}$ & $\begin{array}{c}\text { Kearifan Lokal } \\
\text { Masyarakat Adat } \\
\text { Silungkang } \\
\end{array}$ & Nilai yang Terkandung \\
\hline 1 & $\begin{array}{l}\text { Mengazankan } \\
\text { atau } \\
\text { mengiqomatkan }\end{array}$ & $\begin{array}{l}\text { Syarak mangato } \\
\text { adat memakai } \\
\text { (Agama mengajarkan, } \\
\text { adat memakai) }\end{array}$ & $\begin{array}{c}\text { Orang tua si anak (Pangka) telah } \\
\text { melakukan kewajibannya } \\
\text { untukmengazankan atau } \\
\text { mengiqomatkan anaknya sesuai } \\
\text { dengan ajaran agama Islam yang } \\
\text { dianutnya }\end{array}$ \\
\hline \multirow{4}{*}{2} & \multirow{4}{*}{$\begin{array}{c}\text { Mancoliak } \\
\text { (melihat) }\end{array}$} & $\begin{array}{c}\text { Urang kampuang } \\
\text { dipatenggangkan } \\
\text { (Menenggang orang } \\
\text { kampung/saling tenggang } \\
\text { rasa) }\end{array}$ & $\begin{array}{l}\text { Pihak keluarga si } r \text { anak } \\
\text { menghargai keberadaan } \\
\text { kampung. }\end{array}$ \\
\hline & & $\begin{array}{l}\text { Barek sapikua ringan } \\
\text { sajinjiang } \\
\text { (Berat sama dipikul } \\
\text { ringan sama dijinjing) }\end{array}$ & $\begin{array}{l}\text { Orang tua si anak menghargai } \\
\text { atas perhatian dari pihak } \\
\text { keluarga dan orang kampungnya. }\end{array}$ \\
\hline & & $\begin{array}{c}\text { Baranak pisang } \\
\text { barinduak bako } \\
\text { (saling menjaga hubungan } \\
\text { kekeluargaan) }\end{array}$ & $\begin{array}{c}\text { Pihak keluarga ayah si anak } \\
\text { (induak bako) selalu memberi } \\
\text { perhatian dan menjaga hubungan } \\
\text { kekerabatan dengan orang tua si } \\
\text { anak }\end{array}$ \\
\hline & & $\begin{array}{l}\text { Tenggang raso } \\
\text { (Tenggang Rasa) }\end{array}$ & $\begin{array}{l}\text { Si Pangka (orang tua si anak) } \\
\text { menghargai keberadaan pihak } \\
\text { keluarganya (induak bakonya). }\end{array}$ \\
\hline 3 & Mengakikahkan & $\begin{array}{l}\text { Syarak mangato } \\
\text { adat memakai } \\
\\
\text { (Agama mengajarkan, } \\
\text { adat memakai) }\end{array}$ & $\begin{array}{c}\text { Orang tua si anak telah } \\
\text { melakukan kewajibannya untuk } \\
\text { mengakikahkan anaknya sesuai } \\
\text { dengan ajaran agama Islam yang } \\
\text { dianutnya }\end{array}$ \\
\hline \multirow[t]{2}{*}{4} & \multirow{2}{*}{$\begin{array}{l}\text { Membawa } \\
\text { turun mandi }\end{array}$} & $\begin{array}{l}\text { Iduik dikanduang adat, } \\
\text { mati dikanduang tanah } \\
\text { (Hidup dikandung adat, } \\
\text { mati dikandung tanah) }\end{array}$ & $\begin{array}{c}\text { Orang tua si anak harus } \\
\text { mengikuti pelaksanaan acara } \\
\text { turun mandi si anak yang menjadi } \\
\text { norma aturan masyarakat } \\
\text { setempat. }\end{array}$ \\
\hline & & $\begin{array}{c}\text { Dapek musibah } \\
\text { bahambauan, mandapek } \\
\text { kebaikan bahimbauan }\end{array}$ & $\begin{array}{l}\text { Orang tua si anak berkewajiban } \\
\text { mengundang seluruh keluarga } \\
\text { dan kerabat dekat untuk } \\
\text { menghadiri acara turun mandi si }\end{array}$ \\
\hline
\end{tabular}




\begin{tabular}{|c|c|c|c|}
\hline & & $\begin{array}{c}\text { (Dapat musibah } \\
\text { diimbaukan, dapat } \\
\text { kebaikan diimbaukan) }\end{array}$ & anak \\
\hline & & $\begin{array}{c}\text { Baranak pisang } \\
\text { barinduak bako } \\
\text { (Saling menjaga } \\
\text { hubungan kekeluargaan) }\end{array}$ & $\begin{array}{l}\text { Pihak keluarga ayah si anak } \\
\text { (induak bako) selalumemberi } \\
\text { perhatian dan ikut sertadalam } \\
\text { acara turun mandi si anak untuk } \\
\text { menjaga hubungan kekerabatan } \\
\text { dengan orang tua si anak }\end{array}$ \\
\hline 5 & $\begin{array}{c}\text { Manyingau } \\
\text { (Melihat) }\end{array}$ & $\begin{array}{l}\text { Nan tuo dihormati, nan } \\
\text { ketek disayangi, samo } \\
\text { gadang baok bakawan } \\
\text { (Yang tua dihormati, yang } \\
\text { muda disayangi, yang } \\
\text { sebaya dikawani) }\end{array}$ & $\begin{array}{c}\text { Pihak mintuo (istri mamak) selalu } \\
\text { memberi perhatian dengan tujuan } \\
\text { menjaga hubungan kekeluargaan } \\
\text { dengan pihak si Pangka }\end{array}$ \\
\hline & & $\begin{array}{l}\text { Saiyo sakato } \\
\text { (Seia sekata) }\end{array}$ & $\begin{array}{c}\text { Semua pihak induak bako } \\
\text { bekerjasama untuk melakukan } \\
\text { prosesi penjemputan si anak }\end{array}$ \\
\hline 6 & $\begin{array}{c}\text { Manjopulk } \\
\text { (Menjemput) }\end{array}$ & $\begin{array}{c}\text { Baranak pisang } \\
\text { barinduak bako } \\
\text { (Saling menjaga } \\
\text { hubungan kekeluargaan) }\end{array}$ & $\begin{array}{l}\text { Pihak keluarga ayah si anak } \\
\text { (induak bako) ikut serta dalam } \\
\text { prosesi menjemput si anak untuk } \\
\text { menjaga hubungan kekerabatan } \\
\text { dengan orang tua si anak. }\end{array}$ \\
\hline 7 & Mengkhitankan & $\begin{array}{l}\text { Syarak mangato } \\
\text { adat memakai } \\
\text { (Agama mengajarkan, } \\
\text { adat memakai) }\end{array}$ & $\begin{array}{c}\text { Orang tua si anak telah } \\
\text { melakukan kewajibannya untuk } \\
\text { mengkhitankan anaknya sesuai } \\
\text { dengan ajaran agama Islam yang } \\
\text { dianutnya }\end{array}$ \\
\hline
\end{tabular}

\section{PENUTUP}

Tradisi dapat menghasilkan suatu kearifan lokal yang mengandung nilai kecerdasan, pengetahuan dan moral untuk membangun dasar peradaban suatu masyarakat. Adapun nilai-nilai kearifan lokal yang dapat ditemui dalam tradisi mancoliak anak pada masyarakat adat Silungkang, yakni : agama mengajarkan adat memakai, menenggang orang kampung/saling tenggang rasa, berat sama dipikul ringan sama dijinjing, saling menjaga hubungan kekeluargaan, hidup dikandung adat mati dikandung tanah, dapat musibah diimbaukan dapat kebaikan 
diimbaukan, yang tua dihormati yang muda disayangi yang sebaya dikawani, dan seia sekata. Oleh karena itu melihat begitu besarnya fungsi dari suatu kearifan lokal itu alangkah baiknya agar seluruh tradisi dalam kebudayaan yang ada di Provinsi Sumatra Barat selalu dijaga dan dipertahankan keberadaanya agar tidak tergerus dan punah (Pudentia) oleh globalisasi. 


\section{DAFTAR PUSTAKA}

Aprianto, Yudie, Ilham Akbar Pardede dan Edo Ryzki Fernando.2008.Kearifan Lokal Dalam Mewujudkan Pengelolaan Sumberdaya Air yang Berkelanjutan. PKL Penulisan Ilmiah. IPB Bogor

Anton dan Marwati, 2015."Ungkapan Tradisional Dalam Upacara Adat Perkawinan Masyarakat Bajo di Pulau Balu Kabupaten Muna Barat".Jurnal Humanika, No. 15, Vol. 3, hal :1-13

Abdullah, Irwan.2010.Konstruksi dan Reproduksi Kebudayaan. Yogyakarta: Pustaka Pelajar.

Bakhtiar, Dian.2016. "Peran Pendidikan, Sains, dan Teknologi dalam Membangun Intelektual Bangsa dan Menjaga Budaya Nasional di Era MEA”.Seminar Nasional Pendidikan, ISSN : 2527 - 5917, Vol.1, hal : 650-660

Creswell, J, W. 2012. Research Design Pendekatan Kualitatif, Kuantitatif dan Mix, Cetakan ke-2,Yogyakarta:Pustaka Pelajar

Dt. Rangkayo Bosa, Syahrudin S. 2004. Adat Istiadat dan Monografi Nagari Silungkang. Karapatan Adat Nagari (KAN) Kanagarian Silungkang

Greertz, Clifford.2007.Abangan, Santri, Priyayi dalam Masyarakat Jawa. Jakarta. Pustaka Jaya

KBBI. 2002. Edisi Ketiga.Cetakan 3.Jakarta:Balai Pustaka

Koentjaraningrat.1993.Metode Penelitian Masyarakat.Jakarta.PT Gramedia Pustaka Utama

Konradus, Danggur.2018."Kearifan Lokal Terbonsai Arus Globalisasi: Kajian Terhadap Eksistensi Masyarakat Hukum Adat”.Masalah - Masalah Hukum, Jilid 47 No. 1,hal : 81-88

Pintenate, Amalia dan, Bukhari.2017."Pacuan Kuda Dalam Kajian Sosiologi (Suatu Penelitian di Kabupaten Bener Meriah)".Jurnal Ilmiah Mahasiswa FISIP Unsyiah, Volume 2, Nomor 2.Hal : 907 - 926

Prasetyo, Zuhdan K. 2013. Pembelajaran Sains Berbasis Kearifan Lokal. Prosiding Seminar Nasional Fisika dan Pendidikan Fisika. Surakarta: FKIPUNS,hal 1-14

Romarak Ap, Alfasis.2018."Snap Mor (Tradisi Penangkapan Ikan Masyarakat Biak)”.Jurnal Ilmu BudayaVolume 6, Nomor 2, hal :196-206 
Sabandiah, Raithah Noor dan Endra Wijaya.2018.'Diskriminasi Terhadap Agama Tradisional Masyarakat Hukum Adat Cigugur (Discrimination against Traditional Beliefs of Cigugur Indigenous Community)".Jurnal Penelitian Hukum DE JURE, ISSN 1410-5632 Vol. 18 No. 3, September: 335 - 352

Salim, H.Munir.2016."Adat Sebagai Budaya Kearifan Lokal Untuk Memperkuat Eksistensi Adat ke Depan”. Al-Daulah Vol. 5 / No. 2, hal : 244-254

Sukmayadi, Trisna. 2018."Nilai-Nilai Kearifan Lokal Dalam Pandangan Hidup Masyarakat Adat Kampung Kuta".Jurnal Pancasila dan Kewarganegaraan.JPK: Jurnal Pancasila dan Kewarganegaraan, Vol. 3, No. 1, Januari ISSN 2527-7057 (Electronic), ISSN 2545-2683 (Print)

Widyaningrum,Listyani. 2017."Tradisi Adat Jawa Dalam Menyambut Kelahiran Bayi (Studi Tentang Pelaksanaan Tradisi Jagongan Pada Sepasaran Bayi) di Desa Harapan Harapan Jaya Kecamatan Pangkalan Kuras Kabupaten Pelalawan”.JOM FISIP Vol. 4 No. 2, hal :1-15

Zulkarnain, Asdi Agustar, dan Rudi Febriamansyah.2008.'Kearifan Lokal Dalam Pemanfaatan Dan Pelestarian Sumberdaya Pesisir" (Studi Kasus di Desa Panglima Raja Kecamatan Concong Kabupaten Indragiri Hilir Propinsi Riau). Jurnal Agribisnis Kerakyatan, Volume 1, Nomor 1. Juli 2008, hal 6984 